\title{
Study on Maize-Sesamum Cropping System as Influenced by Weed and Organic Nutrient Management on Yield and Soil Health under Rainfed Condition of North East India
}

\author{
Moasunep ${ }^{1}$, J.K. Choudhary ${ }^{2}$ and N. Khumdemo Ezung ${ }^{3 *}$ \\ ${ }^{1}$ Department of Agriculture, Government of Nagaland, Kohima, Nagaland-797001, India \\ ${ }^{2}$ Department of Agronomy, AAU, Jorhat, Assam-785013, India \\ ${ }^{3} \mathrm{KVK}$, Kiphire, ICAR for NEH Region, Nagaland Centre, India \\ *Corresponding author
}

\section{Keywords}

Weed management,

Fertility

management,

Cropping system,

Yield, Soil health

Article Info

Accepted:

04 August 2019

Available Online:

10 September 2019

\section{A B S T R A C T}

An experiment was carried out at the Instructional-Cum-Research farm, Assam Agricultural University, Jorhat during 2013 and 2014 to study the effect of fertility management $\left(F_{0}-\right.$ control, $F_{1}-2.5$ t/ha enriched compost, $F_{2}-5.0$ t/ha enriched compost $)$ and weed management $\left(\mathrm{W}_{0^{-}}\right.$-weedy check, $\mathrm{W}_{1^{-}}$hand hoeing and earthing up at 20 and 50 DAS, $\mathrm{W}_{2}$-in situ cowpea mulching upto $50 \mathrm{DAS}, \mathrm{W}_{3^{-}}$in situ blackgram mulching upto 50 DAS) in maize and also to study the carry-over effects of these treatments on the succeeding sesamum crop in a split-plot design with 3 replications. The soil of the experimental field was sandy loam in texture, acidic in reaction ( $\mathrm{pH} 5.33)$, medium in soil organic $\mathrm{C}(0.51 \%)$, medium in available $\mathrm{N}(318.93 \mathrm{~kg} / \mathrm{ha}), \mathrm{P}_{2} \mathrm{O}_{5}(32.95 \mathrm{~kg} / \mathrm{ha})$ and $\mathrm{K}_{2} \mathrm{O}$ $(167.54 \mathrm{~kg} / \mathrm{ha})$. Application of $\mathrm{F}_{2}$ significantly produced the highest yield of maize (2322.33 kg/ha in 2013 and $2178.29 \mathrm{~kg} / \mathrm{ha}$ in 2014 ) as compared to application of $F_{1}$ and $\mathrm{F}_{0}$. Fertility management interacted with weed management significantly and the best combination was $\mathrm{F}_{2} \mathrm{~W}_{1}$ (grain yield of $4723.81 \mathrm{~kg} / \mathrm{ha}$ in 2013 and $4507.24 \mathrm{~kg} / \mathrm{ha}$ in 2014). Fertility management during maize seemed to significantly improve the growth and yield of sesamum and the best treatment was application of $\mathrm{F}_{2}$ in maize (seed yield of 589.08 $\mathrm{kg} / \mathrm{ha}$ in 2013 and $402.78 \mathrm{~kg} / \mathrm{ha}$ in 2014). The interaction effect of $\mathrm{F}$ and $\mathrm{W}$ on succeeding sesamum was significant only during 2014 for yield. Application of $F_{2}$ and $W_{1}$ in maize maintained significantly higher organic $\mathrm{C}$, residual soil available $\mathrm{N}, \mathrm{P}_{2} \mathrm{O}_{5}$ and $\mathrm{K}_{2} \mathrm{O}$ in the maize-sesamum cropping sequence compared to other treatments.

\section{Introduction}

In India, maize (Zea mays L.) is the third most important food crop mainly grown during kharif season covering $80 \%$ of the total maize growing area. It is reported that maize being a rainy season wide spaced crop meets heavy competition from weeds (Patel et al., 2006;
Dass et al., 2012) and thereby a huge negative impact on its yield due to this strive (Rao et al., 2009; Bijanzadeh and Ghadiri, 2006; Alok et al., 2012). Cropping system in the NE hill region is also predominantly rice based mono cropping with little exception in the state of Sikkim where maize is the main food crop. Rice and maize cultivation in the region is 
under low-input low-risk and low yield condition. In order to make the region self sufficient in food grain production, the productivity of rice and maize has to be increased from the present level. The farming in the north-eastern region is organic by default without application of any chemical fertilizers resulting in lower production level when compared to the rest of the country. However, simply by adopting low cost agrotechniques like improved variety, proper time of sowing, intercultural practices, effective recycling of resources etc., yield can be increased significantly. Organic manures improves soil physical, biological and chemical properties (Delate and Camberdella, 2004; Tiwari et al., 2002 and Edmeades, 2003; Efthimiadou et al., 2009) of the soil which in turn increases the yield of crops (Kumar et al., 2007; Mehta et al., 2005; Mugwe et al., 2007). Taking into all the above points under consideration, the experiment was initiated to study the influence of live mulching and organic nutrient management on yield of crop and soil health in maize-sesamum cropping systems.

\section{Materials and Methods}

The experiment was conducted at the Instructional-cum-Research (ICR) farm, Assam Agricultural University, Jorhat during the year 2012-2013 and 2013-2014. The experiment was laid out in Split Plot Design (SPD) comprising of fertility management $\left(\mathrm{F}_{0}\right.$ - control, $F_{1}$ - 2.5 t/ha enriched compost, $F_{2}$ $5.0 \mathrm{t} / \mathrm{ha}$ enriched compost) as the main factor and weed management $\left(\mathrm{W}_{0}\right.$-weedy check, $\mathrm{W}_{1^{-}}$ hand hoeing and earthing up 20 and 50 DAS, $\mathrm{W}_{2}$-in situ cowpea mulching upto 50 DAS, $\mathrm{W}_{3-}$ in situ blackgram mulching upto 50 DAS) as the sub factor in maize and these treatments were carried over to the succeeding crop sesamum to study the residual effect. The soil was sandy loam with $\mathrm{pH} 5.33$, organic carbon (OC) $0.51 \%$, available $\mathrm{N} 318.93 \mathrm{~kg} / \mathrm{ha}$, available $\mathrm{P}_{2} \mathrm{O}_{5}$ 32.95, available $\mathrm{K}_{2} \mathrm{O} 167.54$ $\mathrm{kg} / \mathrm{ha}$. Maize variety Dekalb $900 \mathrm{~m}$ Gold and sesamum Koliabor Til were used for undertaking the experiment, whereas, cowpea variety UPC-212 and blackgram variety T9 were taken up as live mulching. Soil moisture content (\%) at 15 days interval during maize and sesamum crop was determined from the soil depth of $0-15 \mathrm{~cm}$ and $15-30 \mathrm{~cm}$. Soil samples from $0-15 \mathrm{~cm}$ depth were collected at the harvest of the first crop, before sowing of the second crop, after harvest of the second crop and various chemical analysis $(\mathrm{pH}$, available $\mathrm{N}$, available $\mathrm{P}_{2} \mathrm{O}_{5}$, available $\mathrm{K}_{2} \mathrm{O}$ as in Jackson, 1973 and organic carbon- Walkey and Black, 1934 were performed.

\section{Results and Discussion}

\section{Grain yield (kg/ha) of maize}

It was observed that the highest maize grain yield $(2322.33 \mathrm{~kg} / \mathrm{ha}$ and $2178.29 \mathrm{~kg} / \mathrm{ha}$ grain during 2013 and 2014, respectively) was obtained with the application of $F_{2}$ followed by $\mathrm{F}_{1}$ (Table 1$)$.

The data further revealed that $\mathrm{W}_{1}$ could significantly increase the maize grain yield (3014.59 kg/ha, 2849.24 kg/ha in 2013 and 2014 , respectively) as compared to the rest of the treatments (Table 1).

The interaction effect revealed that at the same level of organic nutrition $(\mathrm{F})$, hand hoeing and earthing up at 20 and 50 days $\left(\mathrm{W}_{1}\right)$ outyielded the other treatments. At the same or different level of non-herbicidal weed management (W), 5.0 t/ha enriched compost $\left(\mathrm{F}_{2}\right)$ application recorded the best grain and stover yield of maize as compared to the other treatments. Considering all the treatment combinations, it was observed that the application of $\mathrm{F}_{2} \mathrm{~W}_{1}$ resulted in significantly the best grain yield of maize $(4723.81 \mathrm{~kg} / \mathrm{ha}$, $4507.24 \mathrm{~kg} / \mathrm{ha}$ in 2013 and 2014, 
respectively). The next best treatment was $\mathrm{F}_{2} \mathrm{~W}_{1}$ which recorded the grain yield of $3468.14 \mathrm{~kg} / \mathrm{ha}, 3293.16 \mathrm{~kg} / \mathrm{ha}$ respectively (Table 1).

As due to adoption of non-herbicidal weed management, weeds were efficiently controlled; significant improvement in growth of maize could be achieved by organic nutrition through application of enriched compost. Thus, $\mathrm{F}_{2} \mathrm{~W}_{1}$ followed by $\mathrm{F}_{1} \mathrm{~W}_{1}$ proved to be effective in weed suppression and efficient in producing higher maize yield. The efficacy of non-herbicidal methods in managing the weeds and increasing the yield in maize was highlighted by several workers (Kamble et al., 2005; Nagalakshmi et al., 2006 and Sarma and Gautam, 2010). Efficacy of organic nutrition for improving both growth and yield of maize too was reported by some workers (Sekhon and Agarwal, 1994; Khan et al., 2008; Ogundare et al., 2012 and Choudhary and Kumar, 2013). Similar to our findings regarding efficacy of $\mathrm{W}_{2}$ or $\mathrm{W}_{3}$, Echtenkamp and Moomaw (1989) and Uchino et al., (2009) also reported that living mulches competed for nutrients and water with the main crop which might reduce the crop yield.

\section{Seed yield (kg/ha) of sesamum}

The data pertaining to table 1 reveals the yield of the sesamum crop where a significant carryover effect on the yield of sesamum was observed where the application of $\mathrm{F}_{2}$ in maize resulted in highest seed yield $(589.08 \mathrm{~kg} / \mathrm{ha}$ in $2013,402.78 \mathrm{~kg} / \mathrm{ha}$ in 2014) as compared to the rest of the treatments. However, nonherbicidal weed management in maize had no significant effect on seed yield of succeeding crop sesamum (Table 1).

The carryover effect of the treatment interaction was found to be significant only during 2014. Perusal of the data indicated that at the same level of $F_{0}$, in terms of seed yield of sesamum, $\mathrm{W}_{1}$ was significantly superior compared to $\mathrm{W}_{0}, \mathrm{~W}_{2}$ and $\mathrm{W}_{3} . \mathrm{W}_{1}$ and $\mathrm{W}_{3}$ being at par, both recorded significantly more seed of sesamum than $\mathrm{W}_{0}$ and $\mathrm{W}_{2}$. Now at $\mathrm{F}_{2}$ application in maize, in respect of seed yield of sesamum, $\mathrm{W}_{0}$ and $\mathrm{W}_{2}$, both being statistically similar, were significantly superior to $\mathrm{W}_{1}$ and $\mathrm{W}_{3}$. At the same or different level of $\mathrm{W}$ in maize, $\mathrm{F}_{2} \mathrm{~W}_{0}, \mathrm{~F}_{2} \mathrm{~W}_{2}$ and $\mathrm{F}_{2} \mathrm{~W}_{3}$ were statistically similar with regard to seed yield of sesamum but significantly better than the rest of the combinations (Table 1).

Considering the seed yield, it can be seen that although non-herbicidal weed management in maize did not had any carry over effect, organic nutrition in maize with enriched compost application either at $2.5 \mathrm{t} / \mathrm{ha}$ or 5.0 t/ha had significant carry over effects on seed yield of the succeeding crop sesamum. As due to carry over effect of application of enriched compost significantly contributed towards improvement of growth parameters in sesamum as already discussed yield of sesamum was significantly improved as a result.

Perhaps the carry over effect of fertility management helped sesamum plants to be resilient enough vis-à-vis competition of associated weeds. Chopra and Ganguly (1988), Mahala et al., (2006), Jamwal (2006) and Kumar and Dhar (2010) too reported positive residual effects of organic manures in succeeding crops like wheat, rapeseed, etc following maize.

Soil organic C (\%), pH, available $\mathrm{N}, \mathrm{P}_{2} \mathrm{O}_{5}$ and $\mathrm{K}_{2} \mathrm{O}(\mathrm{kg} / \mathrm{ha})$ at harvest of maize during 2013

Application of $\mathrm{F}_{2}$ resulted in significantly higher soil organic $\mathrm{C}(0.54 \%)$, available soil $\mathrm{N}$ $(258.49 \mathrm{~kg} / \mathrm{ha}), \mathrm{P}_{2} \mathrm{O}_{5}(31.22 \mathrm{~kg} / \mathrm{ha})$ and $\mathrm{K}_{2} \mathrm{O}$ $(118.00 \mathrm{~kg} / \mathrm{ha})$ than $\mathrm{F}_{0}$ and the former treatment was at par with $\mathrm{F}_{1}$ in respect of soil available $\mathrm{K}_{2} \mathrm{O}$. On the other hand, $\mathrm{F}_{0}$ and $\mathrm{F}_{1}$ were found to be at par in respect of soil 
organic C $(0.51 \%, 0.53 \%$, respectively). Higher soil $\mathrm{pH}$ was observed due to $\mathrm{F}_{0}(5.30)$ while the least was found in $F_{2}$ (5.19) (Table 2).

$\mathrm{W}_{0}$ recorded the highest soil available $\mathrm{N}$ (261.89 kg/ha), $\mathrm{P}_{2} \mathrm{O}_{5}(30.53 \mathrm{~kg} / \mathrm{ha})$ and $\mathrm{K}_{2} \mathrm{O}$ $(121.64 \mathrm{~kg} / \mathrm{ha}) . \mathrm{W}_{2}$ and $\mathrm{W}_{3}$ were noted to be at par in respect of available soil $\mathrm{N}$, the later being the worst. Treatments $\mathrm{W}_{1}, \mathrm{~W}_{2}$ and $\mathrm{W}_{2}$, $\mathrm{W}_{3}$ were at par respectively in case of soil available $\mathrm{P}_{2} \mathrm{O}_{5} . \mathrm{W}_{1}, \mathrm{~W}_{2}$ and $\mathrm{W}_{3}$ were at par, in respect of soil available $\mathrm{K}_{2} \mathrm{O}$.

The interaction effect reveals that at the same level of $\mathrm{F}_{0}$, both $\mathrm{W}_{0}$ and $\mathrm{W}_{1}$ being statistically at par, were significantly better in respect of soil available $\mathrm{P}_{2} \mathrm{O}_{5}$ whereas, in case of soil available $\mathrm{K}_{2} \mathrm{O}, \mathrm{W}_{0}$ was significantly better than the $\mathrm{W}_{1}, \mathrm{~W}_{2}$ and $\mathrm{W}_{3}$. Now, at the same level of $\mathrm{F}_{1}, \mathrm{~W}_{0}$ was significantly better than rest of the treatments for soil available $\mathrm{P}_{2} \mathrm{O}_{5}$ and $\mathrm{K}_{2} \mathrm{O}$. In case of $\mathrm{F}_{2}$, both $\mathrm{W}_{0}$ and $\mathrm{W}_{3}$ were statically at par, and significantly better than $\mathrm{W}_{1}$ and $\mathrm{W}_{2}$ for soil available $\mathrm{P}_{2} \mathrm{O}_{5}$ whereas for soil available $\mathrm{K}_{2} \mathrm{O}, \mathrm{W}_{0}$ was significantly the best (Table 3 ).

On the other hand, at the same or different level of $\mathrm{W}$ in maize, $\mathrm{F}_{2} \mathrm{~W}_{0}$ and $\mathrm{F}_{2} \mathrm{~W}_{3}$ were statistically similar and significantly better in respect of soil available $\mathrm{P}_{2} \mathrm{O}_{5}$ and $\mathrm{K}_{2} \mathrm{O}$ than the rest of the treatment combinations.

Soil organic $\mathrm{C}(\%), \mathrm{pH}$, available $\mathrm{N}, \mathrm{P}_{2} \mathrm{O}_{5}$ and $\mathrm{K}_{2} \mathrm{O}(\mathrm{kg} / \mathrm{ha})$ before sowing of sesamum in 2013

The data revealed that application of $\mathrm{F}_{1}$ or $\mathrm{F}_{2}$ resulted in significantly more soil organic $\mathrm{C}$ ( 0.53 and $0.54 \%$, respectively) compared to the $\mathrm{F}_{0}$. In respect of soil $\mathrm{pH}$, on the other hand, $F_{1}$ and $F_{2}$ registered significantly lesser soil $\mathrm{pH}$ than $\mathrm{F}_{0}$ (5.29). In case of soil available $\mathrm{N}$, $F_{1}(254.20 \mathrm{~kg} / \mathrm{ha})$ and $F_{2}(265.50 \mathrm{~kg} / \mathrm{ha})$ both at par, were significantly better than $\mathrm{F}_{0}$. Similar result was obtained with respect to soil available $\mathrm{K}_{2} \mathrm{O}$ (126.14 and $132.75 \mathrm{~kg} / \mathrm{ha}$ in case of $F_{1}$ and $F_{2}$, respectively). Soil available $\mathrm{P}_{2} \mathrm{O}_{5}$ was found to be significantly the highest with $\mathrm{F}_{2}(33.64 \mathrm{~kg} / \mathrm{ha})$ (Table 2).

No treatment of weed management in maize was found to be significantly better than the $\mathrm{W}_{0}$ which registered $264.57 \mathrm{~kg} / \mathrm{ha}$ soil available $\mathrm{N}$ and $31.80 \mathrm{~kg} / \mathrm{ha}$ soil available $\mathrm{P}_{2} \mathrm{O}_{5}$. In case of soil available $\mathrm{K}_{2} \mathrm{O}, \mathrm{W}_{0}$ $(125.43 \mathrm{~kg} / \mathrm{ha})$ was found to at par with $\mathrm{W}_{2}$ $(125.22 \mathrm{~kg} / \mathrm{ha})$ and better than the rest (Table 2).

Study on the treatment interactions revealed that, at the same level of $\mathrm{F}_{0}$, it was observed $\mathrm{W}_{0}$ and $\mathrm{W}_{1}$, both being at par, were significantly better than $\mathrm{W}_{2}$ and $\mathrm{W}_{3}$ in respect of soil available $\mathrm{P}_{2} \mathrm{O}_{5}$. In case of soil available $\mathrm{K}_{2} \mathrm{O}, \mathrm{W}_{1}$ registered the significantly highest $(124.12 \mathrm{~kg} / \mathrm{ha})$. At the same level of $F_{1}$, no treatment was significantly better than $\mathrm{W}_{0}$ in respect of soil available $\mathrm{P}_{2} \mathrm{O}_{5}$. In respect of soil available $\mathrm{K}_{2} \mathrm{O}, \mathrm{W}_{0}$ and $\mathrm{W}_{2}$ both being statistically similar, were significantly better than the other treatments. For the same level of $\mathrm{F}_{2}$ application, $\mathrm{W}_{0}$ and $\mathrm{W}_{3}$ for soil available $\mathrm{P}_{2} \mathrm{O}_{5}$, at par themselves were significantly superior to $\mathrm{W}_{1}$ and $\mathrm{W}_{2}$. $\mathrm{W}_{0}, \mathrm{~W}_{2}$ and $\mathrm{W}_{3}$ for soil available $\mathrm{K}_{2} \mathrm{O}$, being statistically similar, were significantly better than $\mathrm{W}_{1}$ (Table 3 ).

Now, at the same or different level of nonherbicidal weed management (W) in maize, in case of soil available $\mathrm{P}_{2} \mathrm{O}_{5}, \mathrm{~F}_{2} \mathrm{~W}_{0}$ and $\mathrm{F}_{2} \mathrm{~W}_{3}$, both statistically at par, and in case of soil available $\mathrm{K}_{2} \mathrm{O}, \mathrm{F}_{1} \mathrm{~W}_{0}, \mathrm{~F}_{1} \mathrm{~W}_{2}, \mathrm{~F}_{2} \mathrm{~W}_{0}, \mathrm{~F}_{2} \mathrm{~W}_{2}$ and $\mathrm{F}_{2} \mathrm{~W}_{3}$, being statistically similar, were statistically superior to rest of the combinations (Table 3).

Soil organic C (\%), pH, available $\mathrm{N}, \mathrm{P}_{2} \mathrm{O}_{5}$ and $\mathrm{K}_{2} \mathrm{O}(\mathrm{kg} / \mathrm{ha})$ at harvest of sesamum in 2013

Significantly higher soil organic C $(0.55 \%)$, soil available $\mathrm{N}(240.87 \mathrm{~kg} / \mathrm{ha})$ and $\mathrm{K}_{2} \mathrm{O}$ 
(114.22 kg/ha) was recorded with application of $F_{2}$ compared to $F_{0}$. In case of soil available $\mathrm{P}_{2} \mathrm{O}_{5} \quad(29.16 \mathrm{~kg} / \mathrm{ha}), \mathrm{F}_{2}$ was the best. Application of $F_{1}$ and $F_{2}$ were no different from each other in respect of soil organic $\mathrm{C}$, available $\mathrm{N}$ and $\mathrm{K}_{2} \mathrm{O}$ (Table 2).

In case of soil available $\mathrm{N}$ and $\mathrm{P}_{2} \mathrm{O}_{5}$, no weed management treatment could be better than $\mathrm{W}_{0}$ that recorded $232.58 \mathrm{~kg} / \mathrm{ha}$ soil available $\mathrm{N}$ of and $27.09 \mathrm{~kg} / \mathrm{ha}$ soil available $\mathrm{P}_{2} \mathrm{O}_{5}$. In case of $\mathrm{K}_{2} \mathrm{O}, \mathrm{W}_{2}$ and $\mathrm{W}_{3}(104.30 \mathrm{~kg} / \mathrm{ha}$ and $101.33 \mathrm{~kg} / \mathrm{ha}$, respectively) resulted similarly with $\mathrm{W}_{0}(103.45 \mathrm{~kg} / \mathrm{ha}$ ) (Table 2$)$.

At the same level of $\mathrm{F}_{0}$, both $\mathrm{W}_{0}$ and $\mathrm{W}_{1}$ being statistically similar in case of $\mathrm{P}_{2} \mathrm{O}_{5}$ and $\mathrm{W}_{1}$ in case of $\mathrm{K}_{2} \mathrm{O}$ were significantly better than the rest of the treatments. Now, at the same level of $F_{1}$, it was found that $W_{0}$ in case of soil available $\mathrm{P}_{2} \mathrm{O}_{5}$ was significantly superior. In case of soil available $\mathrm{K}_{2} \mathrm{O}, \mathrm{W}_{0}, \mathrm{~W}_{2}$ and $\mathrm{W}_{3}$, were at par, $\mathrm{W}_{1}$ being the inferior amongst all. At the level of $\mathrm{F}_{2}$, in respect of soil available $\mathrm{P}_{2} \mathrm{O}_{5}, \mathrm{~W}_{0}$ and $\mathrm{W}_{3}$ were statistically at par, both being superior to the rest. In case of soil available $\mathrm{K}_{2} \mathrm{O}, \mathrm{W}_{2}$ and $\mathrm{W}_{3}$, being no different from each other, proved to be significantly superior to the rest of the treatments.

At the same or different level of nonherbicidal weed management in maize, $\mathrm{F}_{2} \mathrm{~W}_{0}$, $\mathrm{F}_{2} \mathrm{~W}_{2}$ and $\mathrm{F}_{2} \mathrm{~W}_{3}$ were statistically at par but these were significantly superior in respect of available $\mathrm{P}_{2} \mathrm{O}_{5}$. On the other hand, $\mathrm{F}_{1} \mathrm{~W}_{2}$, $\mathrm{F}_{2} \mathrm{~W}_{0}, \mathrm{~F}_{2} \mathrm{~W}_{2}$ and $\mathrm{F}_{2} \mathrm{~W}_{3}$, statistically similar themselves, recorded significantly more soil available $\mathrm{K}_{2} \mathrm{O}$ than the rest of the treatment combinations (Table 3).

Soil organic C (\%), pH, available $\mathrm{N}, \mathrm{P}_{2} \mathrm{O}_{5}$ and $\mathrm{K}_{2} \mathrm{O}(\mathrm{kg} / \mathrm{ha})$ before sowing of maize during 2014

Application of $\mathrm{F}_{2}$ resulted in significantly more soil organic $\mathrm{C}(0.55 \%)$ than $\mathrm{F}_{0}$. In case of soil available $\mathrm{N}(241.72 \mathrm{~kg} / \mathrm{ha}$ and 229.25 $\mathrm{kg} / \mathrm{ha}$ in case of $\mathrm{F}_{2}$ and $\mathrm{F}_{1}$, respectively) and $\mathrm{K}_{2} \mathrm{O}\left(115.68\right.$ and $106.89 \mathrm{~kg} / \mathrm{ha}$ in case of $\mathrm{F}_{2}$ and $\mathrm{F}_{1}$, respectively), $\mathrm{F}_{2}$ and $\mathrm{F}_{1}$ being at par were significantly superior to $\mathrm{F}_{0}$. On the other hand, in respect of soil available $\mathrm{P}_{2} \mathrm{O}_{5}, \mathrm{~F}_{2}$ (30.36 kg/ha) was significantly superior to $F_{0}$ and $\mathrm{F}_{1}$ (Table 4).

No other treatments of weed management could be significantly better than $\mathrm{W}_{0}$ which recorded the highest soil available $\mathrm{N}$ (233.21 $\mathrm{kg} / \mathrm{ha})$ and soil available $\mathrm{P}_{2} \mathrm{O}_{5}(28.15 \mathrm{~kg} / \mathrm{ha})$. In case of soil available $\mathrm{K}_{2} \mathrm{O}, \mathrm{W}_{2}$ (106.03 $\mathrm{kg} / \mathrm{ha})$ and $\mathrm{W}_{3}(102.63 \mathrm{~kg} / \mathrm{ha})$ were at par with $\mathrm{W}_{0}(104.40 \mathrm{~kg} / \mathrm{ha})$ (Table 4).

At the same level of $\mathrm{F}_{0}$ treatment, $\mathrm{W}_{0}$ and $\mathrm{W}_{1}$, being at par, recorded significantly higher soil available $\mathrm{P}_{2} \mathrm{O}_{5}$ than $\mathrm{W}_{2}$ and $\mathrm{W}_{3}$ whereas in case of soil available $\mathrm{K}_{2} \mathrm{O}, \mathrm{W}_{1}$ was significantly better than the rest of the treatments. At the same or different level of $\mathrm{F}_{1}$, no weed treatment could be better than $\mathrm{W}_{0}$ in respect of soil available $\mathrm{P}_{2} \mathrm{O}_{5}$ whereas, $\mathrm{W}_{2}$ and $\mathrm{W}_{3}$ could be at par with $\mathrm{W}_{0}$ in case of soil available $\mathrm{K}_{2} \mathrm{O}$ were significantly superior to $\mathrm{W}_{1}$. In case of same level of $F_{2}$, it was noted that $\mathrm{W}_{0}$ and $\mathrm{W}_{3}$, both being similar, recorded significantly higher soil available $\mathrm{P}_{2} \mathrm{O}_{5}$. In case of soil available $\mathrm{K}_{2} \mathrm{O}, \mathrm{W}_{2}$ and $\mathrm{W}_{3}$, both being statistically similar were significantly better than the rest. The data further showed that at the same or different level of weed management in maize, $\mathrm{F}_{2} \mathrm{~W}_{0}, \mathrm{~F}_{2} \mathrm{~W}_{2}$ and $\mathrm{F}_{2} \mathrm{~W}_{3}$, statistically being similar, were significantly better in respect of soil available $\mathrm{P}_{2} \mathrm{O}_{5}$ whereas, $\mathrm{F}_{1} \mathrm{~W}_{2}, \mathrm{~F}_{2} \mathrm{~W}_{0}, \mathrm{~F}_{2} \mathrm{~W}_{2}$ and $\mathrm{F}_{2} \mathrm{~W}_{3}$, no different from each other, recorded significantly more $\mathrm{K}_{2} \mathrm{O}$ than rest of the combinations (Table 3 ).

Soil organic C (\%), pH, available $\mathrm{N}, \mathrm{P}_{2} \mathrm{O}_{5}$ and $\mathrm{K}_{2} \mathrm{O}(\mathrm{kg} / \mathrm{ha})$ at harvest of maize in 2014

It was evident that application of $\mathrm{F}_{2}$ resulted in significantly more soil organic C (0.56\%), available $\mathrm{N} \quad(189.98 \mathrm{~kg} / \mathrm{ha}), \mathrm{P}_{2} \mathrm{O}_{5} \quad(27.39$ 
$\mathrm{kg} / \mathrm{ha})$ and $\mathrm{K}_{2} \mathrm{O}(74.54 \mathrm{~kg} / \mathrm{ha})$ than other treatments. On the other hand, $\mathrm{F}_{2}$ resulted in significantly lower soil $\mathrm{pH}$ (5.14) compared with either $F_{0}$ or $F_{1}$ (Table 4).

It was observed that $\mathrm{W}_{0}$ treatment recorded significantly more soil available N (193.48 kg/ha, Fig. 4.3), $\mathrm{P}_{2} \mathrm{O}_{5}$ (25.92kg/ha, Fig. 4.5) and $\mathrm{K}_{2} \mathrm{O}(70.86 \mathrm{~kg} / \mathrm{ha})$ than rest of the treatments (Table 4).

At the same level of $\mathrm{F}_{0}$ fertility, $\mathrm{W}_{1}$ resulted in significantly more soil available $\mathrm{N}, \mathrm{P}_{2} \mathrm{O}_{5}$ and $\mathrm{K}_{2} \mathrm{O}$. Now, at the same level of $\mathrm{F}_{1}$, it was clear that $\mathrm{W}_{0}$ in case of soil available $\mathrm{N}, \mathrm{P}_{2} \mathrm{O}_{5}$ and $\mathrm{W}_{0}, \mathrm{~W}_{2}$, both being at par, in case of soil available $\mathrm{K}_{2} \mathrm{O}$ were significantly superior to other treatments. At the same level of $\mathrm{F}_{2}, \mathrm{~W}_{0}$ for $\mathrm{N}, \mathrm{P}_{2} \mathrm{O}_{5} ; \mathrm{W}_{0}, \mathrm{~W}_{2}$ and $\mathrm{W}_{3}$, all statistically similar for $\mathrm{K}_{2} \mathrm{O}$, were significantly superior to rest of the treatments. At the same or different level of non-herbicidal weed management (W), $\mathrm{F}_{2} \mathrm{~W}_{0}$ in case of soil available $\mathrm{N}$ and $\mathrm{P}_{2} \mathrm{O}_{5}$ and $\mathrm{F}_{1} \mathrm{~W}_{0}, \mathrm{~F}_{2} \mathrm{~W}_{0}, \mathrm{~F}_{2} \mathrm{~W}_{2}$ and $\mathrm{F}_{2} \mathrm{~W}_{3}$, all being statistically at par for $\mathrm{K}_{2} \mathrm{O}$ were significantly better than the respective other combinations (Table 5).

Soil organic C (\%), pH, available $\mathrm{N}, \mathrm{P}_{2} \mathrm{O}_{5}$ and $\mathrm{K}_{2} \mathrm{O}$ (kg/ha) before sowing of sesamum in 2014

Application of $\mathrm{F}_{2}$ recorded more soil organic C $(0.57 \%)$, available $\mathrm{N}(197.74 \mathrm{~kg} / \mathrm{ha}), \mathrm{P}_{2} \mathrm{O}_{5}$ $(29.44 \mathrm{~kg} / \mathrm{ha})$ and $\mathrm{K}_{2} \mathrm{O}(85.58 \mathrm{~kg} / \mathrm{ha})$ before sowing of sesamum while the next best treatment was $F_{1}$ application. $F_{2}$ also registered lower soil $\mathrm{pH}$ (5.12) while in case of $\mathrm{F}_{0}$ higher soil $\mathrm{pH}$ (5.26) was recorded. Further it was noticed that $F_{1}$ and $F_{2}$ were statistically similar in respect of soil organic $\mathrm{C}, \mathrm{pH}$, available $\mathrm{N}$ and $\mathrm{K}_{2} \mathrm{O}$ (Table 4).

Effect of weed management on available $\mathrm{N}$, $\mathrm{P}_{2} \mathrm{O}_{5}$ and $\mathrm{K}_{2} \mathrm{O}$ in soil before sowing of sesamum in 2014 was found to be significant.
The data revealed that barring $\mathrm{W}_{2}$ which was at par with $\mathrm{W}_{0}$ but was significantly superior to rest of the treatments in respect of soil available $\quad \mathrm{K}_{2} \mathrm{O} \quad(76.27 \mathrm{~kg} / \mathrm{ha}) ;$ no weed management treatments could be significantly better than $\mathrm{W}_{0}$ in respect of soil available $\mathrm{N}$ (196.57 kg/ha) and $\mathrm{P}_{2} \mathrm{O}_{5}(26.90 \mathrm{~kg} / \mathrm{ha})$ (Table 4).

The data reflected that at the same level of $\mathrm{F}_{0}$ in respect of fertility management in maize, $\mathrm{W}_{1}$ resulted in significantly more soil available $\mathrm{N}, \mathrm{P}_{2} \mathrm{O}_{5}$ and $\mathrm{K}_{2} \mathrm{O}$ than others. At the same level of $F_{1}$ application in maize, $W_{0}$ in case of soil available $\mathrm{N}$ and $\mathrm{P}_{2} \mathrm{O}_{5}$ and $\mathrm{W}_{0}$ and $\mathrm{W}_{2}$, statistically at par in case of soil available $\mathrm{K}_{2} \mathrm{O}$ were significantly superior to the respective other treatments. At the same level of $\mathrm{F}_{2}, \mathrm{~W}_{0}$ for soil available $\mathrm{N}$ and $\mathrm{P}_{2} \mathrm{O}_{5}$ was superior to other treatments. In case of soil available $\mathrm{K}_{2} \mathrm{O}, \mathrm{W}_{2}$ and $\mathrm{W}_{3}$, being statistically no different were significantly superior to the rest. On the other hand, at the same or different level of non-herbicidal weed management $(\mathrm{W})$ of maize, no other treatment combination was better than $\mathrm{F}_{2} \mathrm{~W}_{0}$ in case of soil available $\mathrm{N}$ and $\mathrm{P}_{2} \mathrm{O}_{5} ; \mathrm{F}_{2} \mathrm{~W}_{0}, \mathrm{~F}_{2} \mathrm{~W}_{2}$ and $\mathrm{F}_{2} \mathrm{~W}_{3}$, all being statistically at par were significantly better than the rest of the treatment combinations in respect of soil available $\mathrm{K}_{2} \mathrm{O}$ (Table 5).

Soil organic C (\%), pH, available $\mathrm{N}, \mathrm{P}_{2} \mathrm{O}_{5}$ and $\mathrm{K}_{2} \mathrm{O}(\mathrm{kg} / \mathrm{ha})$ at harvest of sesamum in 2014

The perusal of the data reflected that the application of $\mathrm{F}_{2}$ resulted in significantly the highest soil organic $\mathrm{C}(0.57 \%)$, available $\mathrm{N}$ (171.63 kg/ha), $\mathrm{P}_{2} \mathrm{O}_{5}(27.35 \mathrm{~kg} / \mathrm{ha})$ and $\mathrm{K}_{2} \mathrm{O}$ $(68.65 \mathrm{~kg} / \mathrm{ha}) . \mathrm{F}_{1}$ was the second best in this regard (Table 6).

It was observed as compared with $\mathrm{W}_{0}$ which registered the significantly higher values of soil available $\mathrm{N}$ and $\mathrm{P}_{2} \mathrm{O}_{5}(172.56 \mathrm{~kg} / \mathrm{ha} \mathrm{N}$ and 
$24.50 \mathrm{~kg} / \mathrm{ha} \mathrm{P}_{2} \mathrm{O}_{5}$ ), other weed management treatments were inferior barring $\mathrm{W}_{2}$ which was significantly superior to all other treatments in respect of soil available $\mathrm{K}_{2} \mathrm{O}(60.585 \mathrm{~kg} / \mathrm{ha})$ (Table 6).

The data revealed that at the same level of treatment, $\mathrm{F}_{0}, \mathrm{~W}_{1}$ resulted in significantly more soil available $\mathrm{N}, \mathrm{P}_{2} \mathrm{O}_{5}$ and $\mathrm{K}_{2} \mathrm{O}$ than $\mathrm{W}_{0}$, $\mathrm{W}_{2}$ and $\mathrm{W}_{3}$. In the same level of $\mathrm{F}_{1}$, it was noted that $\mathrm{W}_{0}$ for soil available $\mathrm{N}$ and $\mathrm{P}_{2} \mathrm{O}_{5}$; $\mathrm{W}_{0}$ and $\mathrm{W}_{2}$, statistically at par themselves for soil available $\mathrm{K}_{2} \mathrm{O}$, were significantly better than the respective other treatments. At the same level of $\mathrm{F}_{2}$ treatment, $\mathrm{W}_{0}$ for $\mathrm{N}$ and $\mathrm{P}_{2} \mathrm{O}_{5}$ and $\mathrm{W}_{2}$ and $\mathrm{W}_{3}$, statistically no different from each other for $\mathrm{K}_{2} \mathrm{O}$, were significantly superior than the respective other treatments. On the other hand, at the same or different level of weed management (W) in maize, $\mathrm{F}_{2} \mathrm{~W}_{0}$ in case of soil available $\mathrm{N}$ and $\mathrm{P}_{2} \mathrm{O}_{5}$; $\mathrm{F}_{2} \mathrm{~W}_{2}$ and $\mathrm{F}_{2} \mathrm{~W}_{3}$, being statistically similar for soil available $\mathrm{K}_{2} \mathrm{O}$ proved to be significantly superior to rest of the treatment combinations (Table 6).

From the above described findings in respect of soil $\mathrm{pH}$, organic $\mathrm{C}$ and available $\mathrm{N}, \mathrm{P}_{2} \mathrm{O}_{5}$ and $\mathrm{K}_{2} \mathrm{O}$, it could be known that throughout the period of the experiment, fertility management could influence the status of soil organic $\mathrm{C}$ and availability of $\mathrm{N}, \mathrm{P}_{2} \mathrm{O}_{5}$ and $\mathrm{K}_{2} \mathrm{O}$ in soil.

Soil $\mathrm{pH}$ decreased significantly over the period of the study due to enriched compost application in maize compared to no application control. This may be attributed to decomposition and nitrification processes during which various acids were produced (Kalhapure et al., 2013). Soils become acidic because of warm temperature and high rainfall due to which basic cations are leached from the soil profile leaving behind more stable materials rich in $\mathrm{Fe}$ and $\mathrm{Al}$ oxides (Salim et al., 2015)

By comparing soil organic $\mathrm{C}$ from soil analysis prior to beginning of the experiment with the data in this regard from analysis during the period of the experiment at different stages, it appeared that fertility management in maize with enriched compost could maintain a significantly higher level of soil organic $\mathrm{C}$. The utility of organic manure application in maintaining soil organic $\mathrm{C}$ status is an established fact (Diacono and Montemurro, 2010).

Non-herbicidal weed management did not show any effect on soil $\mathrm{pH}$ and soil organic $\mathrm{C}$ which may be attributed to the fact that the experimental period was not sufficient enough to observe significant influence in these aspects. Perhaps, long-term experiments may show significant effect in this regard. In general, due to non-herbicidal weed management during maize, organic $\mathrm{C}$ had increased whereas the soil $\mathrm{pH}$ decreased as compared to initial values at the end of the experiment.

By comparing the data obtained from soil analysis prior to the experiment with the data obtained from later soil analysis at different stages, it may be seen that availability of soil $\mathrm{N}, \mathrm{P}_{2} \mathrm{O}_{5}$ and $\mathrm{K}_{2} \mathrm{O}$ gradually decreased over the period of the experiment. On the other hand, due to either enriched compost application or non-herbicidal weed management in maize during both the years of the experiment, soil available $\mathrm{N}, \quad \mathrm{P}_{2} \mathrm{O}_{5}$ and $\mathrm{K}_{2} \mathrm{O}$ varied significantly. Significantly more available N, $\mathrm{P}_{2} \mathrm{O}_{5}$ and $\mathrm{K}_{2} \mathrm{O}$ recorded due to enriched compost application in the previous season meant that organic nutrition could sustain availability of these major nutrients in soil. 
Table.1 Effect of weed and fertility management and their interaction on grain yield ( $\mathrm{kg} / \mathrm{ha}$ ) of maize and seed yield (kg/ha) of sesamum

\begin{tabular}{|c|c|c|c|c|c|c|c|c|c|c|c|c|}
\hline \multirow{3}{*}{$\begin{array}{c}\text { Treatment } \\
\text { F }\end{array}$} & \multicolumn{8}{|c|}{ Maize } & \multicolumn{4}{|c|}{ Sesamum } \\
\hline & \multirow{2}{*}{\multicolumn{4}{|c|}{2013}} & \multirow{2}{*}{\multicolumn{4}{|c|}{2014}} & \multirow{2}{*}{\multicolumn{2}{|c|}{2013}} & \multirow{2}{*}{\multicolumn{2}{|c|}{2014}} \\
\hline & & & & & & & & & & & & \\
\hline$F_{0}$ & \multicolumn{4}{|c|}{380.18} & \multicolumn{4}{|c|}{314.31} & \multicolumn{2}{|c|}{445.06} & \multicolumn{2}{|c|}{226.92} \\
\hline $\mathbf{F}_{1}$ & \multicolumn{4}{|c|}{1779.74} & \multicolumn{4}{|c|}{1681.83} & \multicolumn{2}{|c|}{556.28} & \multicolumn{2}{|c|}{353.91} \\
\hline $\mathbf{F}_{2}$ & \multicolumn{4}{|c|}{2322.33} & \multicolumn{4}{|c|}{2178.29} & \multicolumn{2}{|c|}{589.08} & \multicolumn{2}{|c|}{402.78} \\
\hline SEm ( $( \pm)$ & \multicolumn{4}{|c|}{17.602} & \multicolumn{4}{|c|}{16.414} & \multicolumn{2}{|c|}{9.823} & \multicolumn{2}{|c|}{6.105} \\
\hline $\begin{array}{c}\text { CD } \\
(P=0.05)\end{array}$ & \multicolumn{4}{|c|}{69.113} & \multicolumn{4}{|c|}{64.450} & \multicolumn{2}{|c|}{38.570} & \multicolumn{2}{|c|}{23.970} \\
\hline \multicolumn{13}{|l|}{ W } \\
\hline $\mathbf{W}_{\mathbf{0}}$ & \multicolumn{4}{|c|}{1050.43} & \multicolumn{4}{|c|}{944.64} & 54 & .71 & 335 & .42 \\
\hline $\mathbf{W}_{1}$ & & 301 & .59 & & & 284 & .24 & & 52 & .02 & 33 & .53 \\
\hline $\mathbf{W}_{2}$ & & & 44 & & & 85 & .06 & & 53 & 17 & 313 & .96 \\
\hline $\mathbf{W}_{\mathbf{3}}$ & & & 88 & & & $91^{\prime}$ & 96 & & 51 & 67 & $32 ?$ & .56 \\
\hline $\operatorname{SEm}( \pm)$ & & & & & & 17. & & & 10 & 90 & 7.6 & 37 \\
\hline $\begin{array}{c}\text { CD } \\
(P=0.05)\end{array}$ & & & 79 & & & 52. & & & & & $\mathrm{~N}$ & \\
\hline F X W & & & & & & & & & & & $*$ & \\
\hline CV (\%) & & & & & & 4. & & & & & 6. & 45 \\
\hline & & & & & & & & & & & 6. & 99 \\
\hline & & & & Year & & & & & & Year & & \\
\hline & & & & & & & & & & 2014 & & \\
\hline & $\mathbf{W}_{0}^{*}$ & $\mathrm{~W}_{1}$ & $\mathbf{W}_{2}$ & $\mathbf{W}_{3}$ & $\mathbf{W}_{0}^{*}$ & $\mathrm{~W}_{1}$ & $\mathbf{W}_{2}$ & $\mathbf{W}_{3}$ & $\mathbf{W}_{0}^{*}$ & $\mathrm{~W}_{1}$ & $\mathbf{W}_{2}$ & $\mathbf{W}_{3}$ \\
\hline $\mathbf{F}_{\mathbf{0}}$ & 226.63 & 851.83 & 219.80 & 222.46 & 173.63 & 747.32 & 168.55 & 167.73 & 227.97 & 312.67 & 191.57 & 175.47 \\
\hline $\mathbf{F}_{1}$ & 1303.78 & 3468.14 & 1104.97 & 1242.08 & 1210.54 & 3293.16 & 1043.88 & 1179.74 & 328.87 & 385.97 & 324.53 & 376.28 \\
\hline $\mathbf{F}_{2}$ & 1620.88 & 4723.81 & 1427.54 & 1517.11 & 1449.75 & 4507.24 & 1349.75 & 1406.42 & 461.43 & 304.97 & 425.77 & 418.93 \\
\hline $\begin{array}{l}\mathbf{D}_{1} \\
\mathbf{D}_{2}\end{array}$ & $\begin{array}{r}\text { SEr } \\
44 \\
37\end{array}$ & $\begin{array}{l}( \pm) \\
109 \\
16\end{array}$ & $\begin{array}{r}\mathrm{CD} \\
131 \\
132\end{array}$ & $\begin{array}{l}=0.05) \\
947 \\
665\end{array}$ & $\begin{array}{c}\text { SEn } \\
30 . \\
32 .\end{array}$ & $\begin{array}{l}( \pm) \\
30 \\
69\end{array}$ & $\begin{array}{r}\text { CD } \\
90 \\
100 \\
\end{array}$ & $\begin{array}{l}=0.05) \\
710 \\
732\end{array}$ & $\begin{array}{r}\mathrm{SEr} \\
13 \\
12\end{array}$ & $\begin{array}{l}( \pm) \\
28 \\
72\end{array}$ & $\begin{array}{c}\text { CD }(1 \\
39 . \\
47 .\end{array}$ & $\begin{array}{l}=0.05) \\
304 \\
371\end{array}$ \\
\hline
\end{tabular}

F- Fertility management, W- Weed management $\mathrm{F}_{0}-$ Control, $\mathrm{F}_{1}-2.5$ t/ha Enriched Compost, $\mathrm{F}_{2}-5.0$ t/ha Enriched Compost; $\mathrm{W}_{0}-\mathrm{Weedy}_{\text {check, }} \mathrm{W}_{1}-\mathrm{Hand}$ hoeing and earthing up at 20 and $50 \mathrm{DAS}, \mathrm{W}_{2}$ - In situ cowpea mulching upto $50 \mathrm{DAS}, \mathrm{W}_{3}$ - In situ blackgram mulching upto 50 DAS

$\mathrm{D}_{1}$ Difference of two $\mathrm{W}$ means at the same level of $\mathrm{F} ; \mathrm{D}_{2}$ Difference of two $\mathrm{F}$ means at the same or different level of $\mathrm{W}$ 
Table.2 Effect of weed and fertility management on soil organic $\mathrm{C}(\%)$, pH, available $\mathrm{N}(\mathrm{kg} / \mathrm{ha}), \mathrm{P}_{2} \mathrm{O}_{5}(\mathrm{~kg} / \mathrm{ha})$ and $\mathrm{K}_{2} \mathrm{O}(\mathrm{kg} / \mathrm{ha})$ at harvest of maize 2013, before sowing of sesamum 2013 and after harvest of sesamum 2013

\begin{tabular}{|c|c|c|c|c|c|c|c|c|c|c|c|c|c|c|c|}
\hline & $\mathbf{C}$ & $\mathbf{p H}$ & $\mathbf{N}$ & $\mathbf{P}_{2} \mathbf{O}_{5}$ & $\mathbf{K}_{2} \mathbf{O}$ & $\mathbf{C}$ & $\mathbf{p H}$ & $\mathbf{N}$ & $\mathbf{P}_{2} \mathbf{O}_{5}$ & $\mathbf{K}_{2} \mathbf{O}$ & $\mathbf{C}$ & pH & $\mathbf{N}$ & $\mathbf{P}_{2} \mathbf{O}_{5}$ & $\mathbf{K}_{2} \mathbf{O}$ \\
\hline $\mathbf{F}$ & \multicolumn{5}{|c|}{ After harvest of maize 2013} & \multicolumn{5}{|c|}{ Before sowing of sesamum 2013} & \multicolumn{5}{|c|}{ After harvest of sesamum 2013} \\
\hline $\mathbf{F}_{\mathbf{0}}$ & 0.51 & 5.30 & 230.37 & 25.06 & 102.86 & 0.51 & 5.29 & 232.70 & 26.10 & 107.12 & 0.51 & 5.29 & 191.36 & 21.84 & 83.09 \\
\hline $\mathbf{F}_{1}$ & 0.53 & 5.24 & 248.12 & 26.83 & 113.53 & 0.53 & 5.21 & 254.20 & 28.56 & 126.14 & 0.54 & 5.23 & 228.58 & 24.06 & 105.83 \\
\hline $\mathbf{F}_{2}$ & 0.54 & 5.19 & 258.49 & 31.22 & 118.00 & 0.54 & 5.17 & 265.50 & 33.64 & 132.75 & 0.55 & 5.20 & 240.87 & 29.16 & 114.22 \\
\hline SEm ( $( \pm)$ & 0.006 & 0.019 & 4.938 & 0.423 & 2.150 & 0.005 & 0.020 & 4.958 & 0.435 & 2.070 & 0.007 & 0.023 & 5.261 & 0.365 & 2.441 \\
\hline $\begin{array}{c}\text { CD } \\
(P=0.05)\end{array}$ & 0.023 & 0.074 & 19.391 & 1.663 & 8.442 & 0.020 & 0.078 & 19.468 & 1.707 & 8.129 & 0.028 & NS & 20.656 & 1.433 & 9.584 \\
\hline \multicolumn{16}{|l|}{ W } \\
\hline $\mathbf{W}_{\mathbf{0}}$ & 0.53 & 5.24 & 261.89 & 30.53 & 121.64 & 0.52 & 5.22 & 264.57 & 31.80 & 125.43 & 0.53 & 5.24 & 232.58 & 27.09 & 103.45 \\
\hline $\mathbf{W}_{1}$ & 0.52 & 5.24 & 248.80 & 25.97 & 108.01 & 0.53 & 5.22 & 251.51 & 27.30 & 116.93 & 0.53 & 5.25 & 220.02 & 23.00 & 95.09 \\
\hline $\mathbf{W}_{2}$ & 0.53 & 5.24 & 237.39 & 26.66 & 108.90 & 0.53 & 5.22 & 245.64 & 29.22 & 125.22 & 0.54 & 5.25 & 215.43 & 24.81 & 104.30 \\
\hline $\mathbf{W}_{3}$ & 0.54 & 5.25 & 234.55 & 27.66 & 107.31 & 0.54 & 5.23 & 241.49 & 29.41 & 120.42 & 0.54 & 5.24 & 213.07 & 25.18 & 101.33 \\
\hline SEm ( \pm$)$ & 0.005 & 0.021 & 3.291 & 0.407 & 1.282 & 0.007 & 0.025 & 3.311 & 0.404 & 1.286 & 0.006 & 0.017 & 3.926 & 0.419 & 1.374 \\
\hline $\begin{array}{c}\text { CD } \\
(P=0.05)\end{array}$ & NS & NS & 9.777 & 1.210 & 3.808 & NS & NS & 9.838 & 1.199 & 3.821 & NS & NS & 11.666 & 1.245 & 4.081 \\
\hline F X W & NS & NS & NS & $* *$ & $* *$ & NS & NS & NS & $* *$ & $* *$ & NS & NS & $\mathrm{S}$ & $* *$ & $* *$ \\
\hline \multirow[t]{2}{*}{ CV (\%) } & 3.82 & 1.24 & 6.96 & 5.29 & 6.68 & 3.39 & 1.31 & 6.85 & 5.12 & 5.88 & 4.58 & 1.53 & 8.27 & 5.05 & 8.37 \\
\hline & 2.75 & 1.18 & 4.02 & 4.41 & 3.45 & 3.76 & 1.45 & 3.96 & 4.11 & 3.16 & 3.37 & 1.00 & 5.35 & 5.02 & 4.08 \\
\hline
\end{tabular}

F- Fertility management, W- Weed management $\mathrm{F}_{0}-$ Control, $\mathrm{F}_{1}-2.5$ t/ha Enriched Compost, $\mathrm{F}_{2}-5.0$ t/ha Enriched Compost; $\mathrm{W}_{0}-\mathrm{Weedy}_{\text {check, }} \mathrm{W}_{1}-\mathrm{Hand}$ hoeing and earthing up at 20 and 50 DAS, $\mathrm{W}_{2}$ - In situ cowpea mulching upto 50 DAS, $\mathrm{W}_{3}$ - In situ blackgram mulching upto 50 DAS

NS Non-significant; ** Significant 
Table.3 Effect of interaction of weed and fertility management on soil available $\mathrm{P}_{2} \mathrm{O}_{5}(\mathrm{~kg} / \mathrm{ha})$ and $\mathrm{K}_{2}(\mathrm{~kg} / \mathrm{ha})$ after harvest of maize 2013, before sowing of sesamum 2013, after harvest of sesamum 2013 and before sowing of maize 2014

\begin{tabular}{|c|c|c|c|c|c|c|c|c|c|c|c|c|c|c|c|c|}
\hline \multirow[t]{3}{*}{ Treatment } & \multicolumn{8}{|c|}{ After harvest of maize 2013} & \multicolumn{8}{|c|}{ Before sowing of sesamum 2013} \\
\hline & \multicolumn{4}{|c|}{$\mathrm{P}_{2} \mathrm{O}_{5}$} & \multicolumn{4}{|c|}{$\mathrm{K}_{2} \mathrm{O}$} & \multicolumn{4}{|c|}{$\mathbf{P}_{2} \mathrm{O}_{5}$} & \multicolumn{4}{|c|}{$\mathrm{K}_{2} \mathrm{O}$} \\
\hline & $\mathbf{W}_{0}{ }^{*}$ & $\mathbf{W}_{1}$ & $\mathbf{W}_{2}$ & $\mathbf{W}_{3}$ & $\mathbf{W}_{0}{ }^{*}$ & $\mathbf{W}_{1}$ & $\mathbf{W}_{2}$ & $\mathbf{W}_{3}$ & $\mathbf{W}_{0}{ }^{*}$ & $\mathrm{~W}_{1}$ & $\mathbf{W}_{2}$ & $\mathbf{W}_{3}$ & $\mathbf{W}_{0}{ }^{*}$ & $\mathrm{~W}_{1}$ & $\mathbf{W}_{2}$ & $\mathbf{W}_{3}$ \\
\hline $\mathbf{F}_{0}$ & 25.61 & 27.55 & 23.62 & 23.45 & 106.07 & 120.63 & 94.21 & 90.55 & 26.42 & 28.38 & 25.06 & 24.52 & 108.77 & 124.12 & 100.10 & 95.48 \\
\hline $\mathbf{F}_{1}$ & 30.69 & 25.47 & 25.12 & 26.05 & 127.50 & 102.00 & 115.69 & 108.92 & 31.73 & 26.62 & 27.94 & 27.97 & 131.17 & 112.36 & 135.81 & 125.21 \\
\hline $\mathbf{F}_{2}$ & 35.30 & 24.88 & 31.23 & 33.47 & 131.34 & 101.40 & 116.81 & 122.45 & 37.26 & 26.89 & 34.65 & 35.75 & 136.35 & 114.31 & 139.75 & 140.57 \\
\hline $\begin{array}{l}\mathbf{D}_{1} \\
\mathbf{D}_{2}\end{array}$ & & & \multicolumn{2}{|c|}{$\begin{array}{c}\mathrm{CD}(\mathrm{P}=0.05) \\
2.096 \\
2.439\end{array}$} & \multicolumn{2}{|c|}{$\begin{array}{c}\text { SEm }( \pm) \\
2.220 \\
3.886\end{array}$} & \multicolumn{2}{|c|}{$\begin{array}{c}\mathrm{CD}(\mathrm{P}=0.05) \\
6.596 \\
10.100\end{array}$} & \multicolumn{2}{|c|}{$\begin{array}{c}\text { SEm }( \pm) \\
0.699 \\
0.830\end{array}$} & \multicolumn{2}{|c|}{$\begin{array}{c}\mathrm{CD}(\mathrm{P}=0.05) \\
2.077 \\
2.457\end{array}$} & \multicolumn{2}{|c|}{$\begin{array}{c}\mathrm{SEm}( \pm) \\
2.228 \\
3.755\end{array}$} & \multicolumn{2}{|c|}{$\begin{array}{c}\mathrm{CD}(\mathrm{P}=0.05) \\
6.618 \\
9.929\end{array}$} \\
\hline \multirow{2}{*}{ Treatment } & \multicolumn{8}{|c|}{ After harvest of sesamum 2013} & \multicolumn{8}{|c|}{ Before sowing of maize 2014} \\
\hline & $\mathrm{W}_{0}{ }^{*}$ & $\mathrm{~W}_{1}$ & $\mathbf{W}_{2}$ & $\mathbf{W}_{3}$ & $\mathrm{~W}_{0}{ }^{*}$ & $\mathrm{~W}_{1}$ & $\mathbf{W}_{2}$ & $\mathbf{W}_{3}$ & $\mathrm{~W}_{0}{ }^{*}$ & $\mathrm{~W}_{1}$ & $\mathbf{W}_{2}$ & $\mathbf{W}_{\mathbf{3}}$ & $\mathrm{W}_{0}{ }^{*}$ & $\mathrm{~W}_{1}$ & $\mathbf{W}_{2}$ & $\mathbf{W}_{3}$ \\
\hline $\mathbf{F}_{0}$ & 22.26 & 23.77 & 20.87 & 20.45 & 86.36 & 96.67 & 76.90 & 72.42 & 23.12 & 24.65 & 21.81 & 21.37 & 87.19 & 97.45 & 78.98 & 73.54 \\
\hline$F_{1}$ & 26.69 & 22.21 & 23.48 & 23.85 & 109.36 & 92.51 & 113.88 & 107.58 & 27.80 & 23.54 & 24.79 & 25.14 & 110.46 & 93.54 & 114.96 & 108.59 \\
\hline $\mathbf{F}_{2}$ & 32.32 & 23.00 & 30.08 & 31.25 & 114.65 & 96.10 & 122.13 & 123.99 & 33.53 & 24.20 & 31.31 & 32.41 & 115.55 & 97.26 & 124.16 & 125.75 \\
\hline $\begin{array}{l}\mathbf{D}_{1} \\
\mathbf{D}_{2}\end{array}$ & $\begin{array}{r}\text { SEI } \\
0 . \\
0 .\end{array}$ & & CD & $\begin{array}{l}=0.05) \\
56 \\
34\end{array}$ & \multicolumn{2}{|c|}{$\begin{array}{l}2.379 \\
4.392\end{array}$} & \multicolumn{2}{|c|}{$\begin{array}{c}7.068 \\
11.271\end{array}$} & $\begin{array}{r}\text { SE } 1 \\
0 . \\
0 .\end{array}$ & $\begin{array}{l}( \pm) \\
26 \\
33\end{array}$ & $\begin{array}{r}\mathrm{CD}( \\
2 \\
2\end{array}$ & $\begin{array}{l}=0.05) \\
57 \\
71\end{array}$ & $\begin{array}{c}\text { SEr } \\
2 . \\
4 .\end{array}$ & $\begin{array}{l}( \pm) \\
80 \\
02\end{array}$ & $\begin{array}{r}\mathrm{CD} \\
1\end{array}$ & $\begin{array}{l}=0.05) \\
073 \\
625\end{array}$ \\
\hline
\end{tabular}

F- Fertility management, W- Weed management $\mathrm{F}_{0}-$ Control, $\mathrm{F}_{1}-2.5$ t/ha Enriched Compost, $\mathrm{F}_{2}-5.0$ t/ha Enriched Compost; $\mathrm{W}_{0}-\mathrm{Weedy}$ check, $\mathrm{W}_{1}-\mathrm{Hand}$ hoeing and earthing up at 20 and $50 \mathrm{DAS}, \mathrm{W}_{2}$ - In situ cowpea mulching upto $50 \mathrm{DAS}, \mathrm{W}_{3}$ - In situ blackgram mulching upto 50 DAS

$\mathrm{D}_{1}$ Difference of two $\mathrm{W}$ means at the same level of F; $\mathrm{D}_{2}$ Difference of two F means at the same or different level of W 
Table.4 Effect of weed and fertility management on soil organic $\mathrm{C}(\%), \mathrm{pH}$, available $\mathrm{N}(\mathrm{kg} / \mathrm{ha}), \mathrm{P}_{2} \mathrm{O}_{5}(\mathrm{~kg} / \mathrm{ha})$ and $\mathrm{K}_{2} \mathrm{O}$ (kg/ha) before sowing of maize 2014, after harvest of maize 2014 and before sowing of sesamum 2014

\begin{tabular}{|c|c|c|c|c|c|c|c|c|c|c|c|c|c|c|c|}
\hline & $\mathbf{C}$ & pH & $\mathbf{N}$ & $\mathbf{P}_{2} \mathbf{O}_{5}$ & $\mathbf{K}_{2} \mathbf{O}$ & $\mathbf{C}$ & pH & $\mathbf{N}$ & $\mathbf{P}_{2} \mathbf{O}_{5}$ & $\mathbf{K}_{2} \mathbf{O}$ & $\mathbf{C}$ & pH & $\mathbf{N}$ & $\mathbf{P}_{2} \mathbf{O}_{5}$ & $\mathrm{~K}_{2} \mathrm{O}$ \\
\hline $\mathbf{F}$ & \multicolumn{5}{|c|}{ Before sowing of maize 2014} & \multicolumn{5}{|c|}{ After harvest of maize 2014} & \multicolumn{5}{|c|}{ Before sowing of sesamum 2014} \\
\hline $\mathbf{F}_{\mathbf{0}}$ & 0.51 & 5.29 & 191.76 & 22.74 & 84.29 & 0.50 & 5.27 & 133.91 & 15.04 & 45.82 & 0.50 & 5.26 & 137.23 & 15.85 & 52.59 \\
\hline $\mathbf{F}_{1}$ & 0.54 & 5.24 & 229.25 & 25.32 & 106.89 & 0.55 & 5.17 & 173.77 & 19.12 & 65.15 & 0.55 & 5.15 & 180.58 & 20.62 & 74.41 \\
\hline $\mathbf{F}_{2}$ & 0.55 & 5.21 & 241.72 & 30.36 & 115.68 & 0.56 & 5.14 & 189.98 & 27.39 & 74.54 & 0.57 & 5.12 & 197.74 & 29.44 & 85.58 \\
\hline $\operatorname{SEm}( \pm)$ & 0.005 & 0.023 & 4.679 & 0.368 & 2.447 & 0.006 & 0.020 & 3.706 & 0.377 & 1.559 & 0.008 & 0.025 & 4.955 & 0.406 & 1.936 \\
\hline $\begin{array}{c}\text { CD } \\
(\mathbf{P}=0.05)\end{array}$ & 0.021 & NS & 18.372 & 1.444 & 9.606 & 0.023 & 0.078 & 14.550 & 1.479 & 6.122 & 0.031 & 0.096 & 19.457 & 1.592 & 7.600 \\
\hline \multicolumn{16}{|l|}{ W } \\
\hline $\mathbf{W}_{\mathbf{0}}$ & 0.53 & 5.25 & 233.21 & 28.15 & 104.40 & 0.53 & 5.19 & 193.48 & 25.92 & 70.86 & 0.54 & 5.18 & 196.57 & 26.90 & 74.17 \\
\hline $\mathbf{W}_{1}$ & 0.53 & 5.25 & 220.62 & 24.13 & 96.08 & 0.54 & 5.19 & 167.89 & 16.31 & 58.93 & 0.54 & 5.17 & 171.04 & 17.38 & 65.40 \\
\hline $\mathbf{W}_{2}$ & 0.53 & 5.25 & 216.05 & 25.97 & 106.03 & 0.54 & 5.20 & 154.85 & 19.68 & 62.12 & 0.54 & 5.19 & 165.41 & 21.88 & 76.27 \\
\hline $\mathbf{W}_{3}$ & 0.54 & 5.24 & 213.75 & 26.31 & 102.63 & 0.55 & 5.19 & 147.33 & 20.16 & 55.44 & 0.55 & 5.18 & 154.40 & 21.73 & 67.60 \\
\hline SEm ( \pm$)$ & 0.005 & 0.018 & 3.936 & 0.419 & 1.374 & 0.006 & 0.019 & 3.099 & 0.491 & 1.308 & 0.006 & 0.018 & 3.240 & 0.492 & 1.891 \\
\hline $\begin{array}{c}\text { CD } \\
(P=0.05)\end{array}$ & NS & NS & 11.695 & 1.246 & 4.083 & NS & NS & 9.207 & 1.459 & 3.885 & NS & NS & 9.628 & 1.462 & 5.619 \\
\hline F X W & NS & NS & NS & $* *$ & $* *$ & NS & NS & $* *$ & $* *$ & $* *$ & NS & NS & $* *$ & $* *$ & $* *$ \\
\hline \multirow[t]{2}{*}{ CV (\%) } & 3.49 & 1.49 & 7.34 & 4.87 & 8.29 & 3.72 & 1.33 & 7.74 & 6.36 & 8.73 & 5.06 & 1.64 & 9.99 & 6.39 & 9.46 \\
\hline & 3.02 & 1.05 & 5.34 & 4.81 & 4.03 & 3.15 & 1.12 & 5.60 & 7.18 & 6.34 & 3.21 & 1.04 & 5.66 & 6.72 & 8.00 \\
\hline
\end{tabular}

F- Fertility management, W- Weed management $\mathrm{F}_{0}-$ Control, $\mathrm{F}_{1}-2.5$ t/ha Enriched Compost, $\mathrm{F}_{2}-5.0$ t/ha Enriched Compost; $\mathrm{W}_{0}-\mathrm{Weedy}_{\text {check, }} \mathrm{W}_{1}-\mathrm{Hand}$ hoeing and earthing up at 20 and 50 DAS, $\mathrm{W}_{2}$ - In situ cowpea mulching upto 50 DAS, $\mathrm{W}_{3}$ - In situ blackgram mulching upto 50 DAS

NS Non-significant; ** Significant 
Table.5 Effect of interaction of weed and fertility management on soil available $\mathrm{N}(\mathrm{kg} / \mathrm{ha}), \mathrm{P}_{2} \mathrm{O}_{5}(\mathrm{~kg} / \mathrm{ha})$ and $\mathrm{K}_{2} \mathrm{O}(\mathrm{kg} / \mathrm{ha})$ after harvest of maize 2014 and before sowing of sesamum 2014

\begin{tabular}{|c|c|c|c|c|c|c|c|c|c|c|c|c|}
\hline \multirow[t]{3}{*}{ Treatment } & \multicolumn{12}{|c|}{ After harvest of maize 2014} \\
\hline & \multicolumn{4}{|c|}{$\mathbf{N}$} & \multicolumn{4}{|c|}{$\mathbf{P}_{2} \mathbf{O}_{5}$} & \multicolumn{4}{|c|}{$\mathrm{K}_{2} \mathrm{O}$} \\
\hline & $\mathbf{W}_{0}^{*}$ & $\mathbf{W}_{1}$ & $\mathbf{W}_{2}$ & $\mathbf{W}_{3}$ & $\mathbf{W}_{\mathbf{0}}^{*}$ & $\mathbf{W}_{1}$ & $\mathbf{W}_{2}$ & $\mathbf{W}_{3}$ & $\mathbf{W}_{0}^{*}$ & $\mathbf{W}_{1}$ & $\mathbf{W}_{2}$ & $\mathbf{W}_{3}$ \\
\hline $\mathbf{F}_{\mathbf{0}}$ & 145.53 & 163.88 & 116.92 & 109.34 & 16.00 & 19.69 & 12.44 & 12.02 & 50.91 & 73.93 & 32.01 & 26.42 \\
\hline $\mathbf{F}_{1}$ & 203.37 & 168.59 & 167.05 & 156.07 & 24.98 & 15.58 & 17.73 & 18.18 & 77.43 & 53.00 & 71.09 & 59.10 \\
\hline \multirow[t]{2}{*}{$\mathbf{F}_{2}$} & 231.54 & 171.21 & 180.58 & 176.58 & 36.78 & 13.67 & 28.85 & 30.26 & 84.24 & 49.86 & 83.25 & 80.81 \\
\hline & \multicolumn{2}{|l|}{$\operatorname{SEm}( \pm)$} & \multirow{3}{*}{\multicolumn{2}{|c|}{$\begin{array}{l}\mathrm{CD}(\mathrm{P}=0.05) \\
15.947 \\
19.868\end{array}$}} & \multirow{3}{*}{\multicolumn{2}{|c|}{$\begin{array}{c}\text { SEm }( \pm) \\
2.379 \\
4.392\end{array}$}} & \multirow{3}{*}{\multicolumn{2}{|c|}{$\begin{array}{c}\mathrm{CD}(\mathrm{P}=0.05) \\
7.068 \\
11.271\end{array}$}} & \multirow{3}{*}{\multicolumn{2}{|c|}{$\begin{array}{c}\operatorname{SEm}( \pm) \\
0.851 \\
0.779\end{array}$}} & \multirow{3}{*}{\multicolumn{2}{|c|}{$\begin{array}{c}\mathrm{CD}(\mathrm{P}=0.05) \\
2.527 \\
2.915\end{array}$}} \\
\hline $\mathbf{D}_{1}$ & & & & & & & & & & & \\
\hline $\mathbf{D}_{2}$ & 6.957 & & & & & & & & & & & \\
\hline \multirow{3}{*}{ Treatment } & \multicolumn{12}{|c|}{ Before sowing of sesamum 2014} \\
\hline & \multicolumn{4}{|c|}{$\mathbf{N}$} & \multicolumn{4}{|c|}{$\mathbf{P}_{2} \mathbf{O}_{5}$} & \multicolumn{4}{|c|}{$\mathbf{K}_{2} \mathbf{O}$} \\
\hline & $\mathbf{W}_{0}^{*}$ & $\mathbf{W}_{1}$ & $\mathbf{W}_{2}$ & $\mathbf{W}_{3}$ & $\mathbf{W}_{0}^{*}$ & $\mathbf{W}_{1}$ & $\mathbf{W}_{2}$ & $\mathbf{W}_{3}$ & $\mathbf{W}_{0}{ }^{*}$ & $\mathbf{W}_{1}$ & $\mathbf{W}_{2}$ & $\mathbf{W}_{3}$ \\
\hline $\mathbf{F}_{\mathbf{0}}$ & 147.75 & 166.10 & 122.19 & 112.90 & 16.59 & 20.31 & 13.49 & 13.01 & 53.17 & 76.88 & 44.40 & 35.93 \\
\hline $\mathbf{F}_{1}$ & 206.54 & 171.94 & 179.36 & 164.50 & 25.81 & 16.50 & 20.20 & 19.97 & 80.59 & 59.98 & 85.30 & 71.76 \\
\hline $\mathbf{F}_{2}$ & 235.41 & 175.09 & 194.68 & 185.78 & 38.30 & 15.32 & 31.93 & 32.21 & 88.75 & 59.33 & 99.13 & 95.12 \\
\hline $\begin{array}{l}\mathbf{D}_{1} \\
\mathbf{D}_{2}\end{array}$ & \multicolumn{2}{|c|}{$\begin{array}{c}\text { SEm }( \pm) \\
5.613 \\
9.030\end{array}$} & \multicolumn{2}{|c|}{$\begin{array}{c}\mathrm{CD}(\mathrm{P}=0.05) \\
16.676 \\
25.905\end{array}$} & \multicolumn{2}{|c|}{$\begin{array}{c}\text { SEm }( \pm) \\
2.379 \\
4.392\end{array}$} & \multicolumn{2}{|c|}{$\begin{array}{c}\mathrm{CD}(\mathrm{P}=0.05) \\
7.068 \\
11.271\end{array}$} & \multicolumn{2}{|c|}{$\begin{array}{c}\text { SEm }( \pm) \\
0.852 \\
0.822\end{array}$} & \multicolumn{2}{|c|}{$\begin{array}{c}\mathrm{CD}(\mathrm{P}=0.05) \\
2.533 \\
3.001\end{array}$} \\
\hline
\end{tabular}

F- Fertility management, W- Weed management $\mathrm{F}_{0}-$ Control, $\mathrm{F}_{1}-2.5$ t/ha Enriched Compost, $\mathrm{F}_{2}-5.0$ t/ha Enriched Compost; $\mathrm{W}_{0}-\mathrm{Weedy}_{\mathrm{C}}$ check, $\mathrm{W}_{1}-\mathrm{Hand}$ hoeing and earthing up at 20 and 50 DAS, $\mathrm{W}_{2}$ - In situ cowpea mulching upto 50 DAS, $\mathrm{W}_{3}$ - In situ blackgram mulching upto 50 DAS

$\mathrm{D}_{1}$ Difference of two W means at the same level of F; $\mathrm{D}_{2}$ Difference of two F means at the same or different level of W 
Table.6 Effect of weed and fertility management and their interaction on soil organic $\mathrm{C}(\%), \mathrm{pH}$, available $\mathrm{N}(\mathrm{kg} / \mathrm{ha}), \mathrm{P}_{2} \mathrm{O}_{5}(\mathrm{~kg} / \mathrm{ha})$ and $\mathrm{K}_{2} \mathrm{O}(\mathrm{kg} / \mathrm{ha})$ at harvest of sesamum, 2014

\begin{tabular}{|c|c|c|c|c|c|c|c|c|c|c|c|c|}
\hline \multirow[t]{2}{*}{ Treatment } & \multicolumn{3}{|c|}{$\mathrm{C}$} & pH & & \multicolumn{2}{|c|}{$\mathbf{N}$} & \multicolumn{3}{|c|}{$\mathbf{P}_{2} \mathbf{O}_{5}$} & \multicolumn{2}{|c|}{$\mathbf{K}_{2} \mathbf{O}$} \\
\hline & \multicolumn{12}{|c|}{2014} \\
\hline \multicolumn{13}{|l|}{$\mathbf{F}$} \\
\hline $\mathbf{F}_{0}$ & \multicolumn{3}{|c|}{0.50} & \multicolumn{2}{|l|}{5.27} & \multicolumn{2}{|c|}{116.39} & \multicolumn{3}{|c|}{13.22} & \multicolumn{2}{|c|}{38.44} \\
\hline $\mathbf{F}_{1}$ & \multicolumn{3}{|c|}{0.56} & \multicolumn{2}{|l|}{5.18} & \multicolumn{2}{|c|}{156.94} & \multicolumn{3}{|c|}{18.53} & \multicolumn{2}{|c|}{58.36} \\
\hline $\mathbf{F}_{2}$ & \multicolumn{3}{|c|}{0.57} & \multicolumn{2}{|l|}{5.15} & \multicolumn{2}{|c|}{171.63} & \multicolumn{3}{|c|}{27.35} & \multicolumn{2}{|c|}{68.65} \\
\hline $\operatorname{SEm}( \pm)$ & \multicolumn{3}{|c|}{0.007} & \multicolumn{2}{|c|}{0.029} & \multicolumn{2}{|c|}{4.265} & \multicolumn{3}{|c|}{0.364} & \multicolumn{2}{|c|}{1.230} \\
\hline $\mathrm{CD}(\mathrm{P}=\mathbf{0 . 0 5})$ & \multicolumn{3}{|c|}{0.028} & \multicolumn{2}{|c|}{ NS } & \multicolumn{2}{|c|}{16.747} & & 1.430 & & 4.82 & \\
\hline W & & & & & & & & & & & & \\
\hline $\mathbf{W}_{\mathbf{0}}$ & & 0.54 & & 5.20 & & & & & 24.50 & & 57.5 & \\
\hline $\mathrm{W}_{1}$ & & 0.55 & & 5.19 & & & & & 15.07 & & 49.68 & \\
\hline $\mathrm{W}_{2}$ & & 0.55 & & 5.20 & & & & & 19.78 & & 60.5 & \\
\hline $\mathbf{W}_{3}$ & & 0.55 & & 5.20 & & & & & 19.45 & & 52.8 & \\
\hline $\operatorname{SEm}( \pm)$ & & 0.008 & & 0.018 & & & & & 0.484 & & 1.41 & \\
\hline $\mathrm{CD}(\mathrm{P}=0.05)$ & & NS & & NS & & & & & 1.437 & & 4.20 & \\
\hline F X W & & NS & & NS & & & & & $* *$ & & $* *$ & \\
\hline $\mathrm{CV}(\%)$ & & 4.53 & & 1.91 & & & & & 6.40 & & 7.72 & \\
\hline & & 4.30 & & 1.03 & & & & & 7.37 & & 7.69 & \\
\hline & & & & & & & & & & & & \\
\hline & & & & & & & & & & & & \\
\hline & & & & & & & & & & & & \\
\hline & $\mathbf{W}_{0}{ }^{*}$ & $\mathrm{~W}_{1}$ & $\mathbf{W}_{2}$ & $\mathbf{W}_{\mathbf{3}}$ & $\mathbf{W}_{0}{ }^{*}$ & $\mathrm{~W}_{1}$ & $\mathbf{W}_{2}$ & $\mathbf{W}_{3}$ & $\mathbf{W}_{0}{ }^{*}$ & $W_{1}$ & $\mathbf{W}_{2}$ & $\mathbf{W}_{3}$ \\
\hline $\mathbf{F}_{\mathbf{0}}$ & 127.08 & 142.43 & 102.91 & 93.16 & 14.01 & 17.28 & 10.96 & 10.64 & 38.86 & 60.91 & 30.80 & 23.21 \\
\hline $\mathbf{F}_{1}$ & 183.16 & 147.51 & 156.56 & 140.53 & 23.68 & 14.00 & 18.63 & 17.80 & 63.69 & 43.17 & 70.53 & 56.05 \\
\hline $\mathbf{F}_{2}$ & 207.43 & 152.58 & 167.11 & 159.39 & 35.80 & 13.95 & 29.74 & 29.93 & 70.06 & 44.96 & 80.42 & 79.14 \\
\hline $\begin{array}{l}\mathbf{D}_{1} \\
\mathbf{D}_{2}\end{array}$ & $\begin{array}{l}\text { SEm }( \pm) \\
4.601 \\
7.737\end{array}$ & & $\begin{array}{l}\text { CD (P } \\
13.672 \\
20.31\end{array}$ & $0.05)$ & $\begin{array}{l}\text { SEm ( } \\
0.838 \\
0.757\end{array}$ & & $\begin{array}{l}\mathrm{CD}(\mathrm{P}= \\
2.489 \\
2.927\end{array}$ & & $\begin{array}{l}\mathrm{SEm}( \pm \\
2.450 \\
2.457\end{array}$ & & $\begin{array}{c}\mathrm{CD}(\mathrm{P}=0 \\
7.278 \\
7.875\end{array}$ & $5 \%)$ \\
\hline
\end{tabular}

F- Fertility management, W- Weed management $\mathrm{F}_{0}-$ Control, $\mathrm{F}_{1}-2.5 \mathrm{t} / \mathrm{ha}$ Enriched Compost, $\mathrm{F}_{2}-5.0$ t/ha Enriched Compost; $\mathrm{W}_{0}$ - Weedy check, $\mathrm{W}_{1}$ - Hand hoeing and earthing up at 20 and 50 DAS, $\mathrm{W}_{2}$ - In situ cowpea mulching upto $50 \mathrm{DAS}, \mathrm{W}_{3}$ - In situ blackgram mulching upto $50 \mathrm{DAS}$

$\mathrm{D}_{1}$ Difference of two $\mathrm{W}$ means at the same level of $\mathrm{F} ; \mathrm{D}_{2}$ Difference of two F means at the same or different level of $\mathrm{W}$

NS Non-significant; ** Significant 
It was obvious to note that during the subsequent crop sesamum, unweeded control plot showed significantly more available $\mathrm{N}$, $\mathrm{P}_{2} \mathrm{O}_{5}$ and $\mathrm{K}_{2} \mathrm{O}$ as it is easily understandable that due to non-herbicidal weed management i.e. hand hoeing and earthing up at 20 and 50 days, in situ cowpea or blackgram mulching upto 50 days during the preceding crop maize, the crop and weeds besides the live mulches absorbed these major nutrients substantially resulting in lesser soil available $\mathrm{N}, \mathrm{P}_{2} \mathrm{O}_{5}$ and $\mathrm{K}_{2} \mathrm{O}$ compared to absorption mainly by weeds only in case of weedy check. Significant interaction between fertility and weed management in this respect highlighted this aspect.

Compared to the initial soil fertility status, it was observed that soil available $\mathrm{N}, \mathrm{P}_{2} \mathrm{O}_{5}$ and $\mathrm{K}_{2} \mathrm{O}$ decreased at the end of the field experiment (after harvest of sesamum, 2014). This may be due to the uptake of nutrients by the maize crop, sesamum crop, weeds, in situ cowpea or blackgram live mulching, leaching loss, volatilization loss, fixation in the soil and also due to the slow release of nutrients from enriched compost even though large quantity of enriched compost @ 2.5 or 5.0 t/ha were applied during the maize crop season in 2013 and 2014. Diacono and Montemurro (2009) on reviewing the experiment conducted by Hartl et al., (2003) and Eghball et al., (2004) concluded that compost application on long-term basis for several years may result in residual effects in respect of soil properties and crop production since only a fraction of the $\mathrm{N}$ and other nutrients becomes available to plants in the first year after application. Eghball and Power (1999) in a four year study found that the estimated $\mathrm{N}$ availability was $40 \%$ for manure and $15 \%$ for compost in the first year and was $18 \%$ for manure and $8 \%$ for compost in the second year after application. Curless et al., (2005) found that an apparent availability of manurial $\mathrm{N}$ from $10 \%$ to $40 \%$, with an overall average across all 3 years and all parameters of $28.6 \%$ for the lower rate and $24.6 \%$ for the high rate and $\mathrm{P}$ availability ranged from $20 \%$ to $90 \%$ with an overall average across all 3 years of $55.4 \%$ for the low and $50.5 \%$ for the high manure rates. Diacono and Montemurro (2009) reviewed the work of Hartl et al., (2003) and stated that soil available potassium (K) content increased on average by $26 \%$, as compared with control, in 5-year compost treatments derived from organic household wastes and yard trimmings.

In conclusions, application of enriched compost resulted in significantly better yield and higher soil fertility level under rainfed maize-sesamum cropping sequence. Hand hoeing and earthing up at 20 and 50 days significantly increased the yield of maize as well as maintain higher soil fertility level of the sequence however no carry over effect was observed in the yield sesamum.

Since the present investigation was carried out during 2013 and 2014 only, experiments are needed to be conducted for more number of years to derive concrete information on long term benefits covering every aspect of management including weed and fertility management from organically managed cropping sequence like maize-sesamum under rainfed situation.

\section{References}

Alok, M., Nupur, M., Singh, B. and Singh, A.K. 2012. Integrated weed management in maize (Zea mays) under rainfed conditions. Indian Journal of Dryland Agricultural Research and Development 27(1):70-73.

Bijanzadeh, E. and Ghadiri, H. 2006. Effect of separate and combined treatments of herbicides on weed control and corn (Zea mays L.) yield. Weed Technology 20: 640-645. 
Brar, B.S., Dhillon, N.S. and China, H.S. 2001. Integrated use of farm yard manure and inorganic fertilizers in maize (Zea mays). Indian Journal of Agricultural Sciences 71(9): 605-607.

Choudhary, V.K. and Kumar, P.S. 2013. Maize production, economics and soil productivity under different organic source of nutrients in eastern Himalayan region, India. International Journal of Plant Production 7(2): 167-186.

Curless, M.A., Kelling, K.A. and Speth, P.E. (2005). Nitrogen and phosphorus availability from liquid dairy manure to potatoes. American Journal of Potato Research 82(4): 287-297.

Dass, S., Kumar, A., Jat, S.L., Parihar, C.M., Singh, A.K., Chikkappa, G.K. and Jat, M.L. 2012. Maize holds a potential for diversification and livelihood security. Indian Journal of Agronomy 57: 32-37.

Delate, K. and Camberdella, C.A. 2004. Agroecosystem performance during transition to certified organic grain production. Agronomy Journal 96(5): 1288-1298.

Diacono, M. and Montemurro, F. 2010. Long-term effects of organic amendments on soil fertility. A review. Agronomy Sustainable Development 30: 401-422.

Echtenkamp, G.W. and Moomaw, R.S. 1989. No-till corn production in a living mulch system. Weed Technology 3: 261-266.

Economou, G.O., Tzakou, A., Gani, A., Yannitsaros, A. and Bilalis, D. 2002. Allelopathic effect of Conyza albida on Avena sativa and Spirodela polyrhiz. Journal of Agronomy and Crop Science 188: 248-253.

Edmeades, D.C. 2003. The long-term effects of manures and fertilizers on soil productivity and quality: A review. Nutrient Cycling in Agroecosystems 66: 165-180.
Efthimiadou, A., Bilalis, D., Karkanis, A., Froud-Williams, B. and Eleftherohorinos, I. 2009. Effects of cultural system (organic and conventional) on growth, photosynthesis and yield components of sweet corn (Zea mays L.), under semiarid environment. Notulae Botanicae Horti Agrobotanici ClujNapoca 2: 105-111.

Eghball, B. and Power, J.F. 1999. Phosphorus and nitrogen- based manure and soil compost application: Corn production and soil phosphorus. Soil Science Society of American Journal 63: 895901.

Eghball, B., Ginting, D. and Gilley, J.E. 2004. Residual effects of manure and compost applications on corn production and soil properties. Agronomy Journal 96: 442-447.

Gaur, A.C. 1982. In: Review of soil research in India. Part 1. Proceedings of 12th International Conference on Soil Science, New Delhi, India, pp. 278-305.

Hartl, W., Putz, B. and Erhart, E. 2003. Influence of rates and timing of biowaste compost application on rye yield and soil nitrate levels. European Journal of Soil Biology 39: 129-139.

Jackson, M.L. 1973. Soil chemical analysis. Prentice Hall of India Pvt. Ltd., New Delhi, pp. 151-153.

Kalhapure, A.H., Shete, B.T. and Dhonde, M.B. 2013. Integrated nutrient management in maize (Zea mays L.) for increasing production with sustainability. International Journal of Agriculture and Food Science 4(3): 195-206.

Kamble, T.C., Kakade, S.U., Nemade, S.U., Pawar, R.V. and Apotikar, V.A. 2005. An integrated weed management in hybrid maize. Crop Research Hisar 29(3): 396-400.

Khan, H., Malik, M., Saleem, M., Khan, H., 
Malik, M. and Saleem, M. 2008. Effect of rate and source of organic material on the production potential of spring maize (Zea mays L.). Pakistan Journal of Agricultural Sciences 45: 40-43.

Kumar, A. and Dhar, S. 2010. Evaluation of organic and inorganic sources of nutrients in maize (Zea mays) and their residual effect on wheat (Triticum aestivum) under different fertility levels. Indian Journal of Agricultural Sciences 80(5): 364-371.

Kumar, P., Halepyati, A.S., Pujari, B.T. and Desai, B.K. 2007. Effect of integrated nutrient management on productivity, nutrient uptake and economics of maize (Zea mays L.) under rainfed condition. Karnataka Journal of Agricultural Sciences 20(3): 462-465.

Labrada, R. 1996. Weed management in rice. In: Auld, B.A. and Kim, K.U. eds. FAO Plant Production and Protection Paper No. 139, pp. 259-272.

Mahala, H.L., Shaktawat, M.S. and Shivran, R.K. 2006. Direct and residual effects of sources and levels of phosphorus and farmyard manure in maize (Zea mays)mustard (Brassica juncea) cropping sequence. Indian Journal of Agronomy 51(1): 10-13.

Mehta, Y.K., Shaktawat, M.S. and Singhi, S.M. 2005. Influence of sulphur, phosphorus and farmyard manure on yield attributes and yield of maize (Zea mays) in southern Rajasthan conditions. Indian Journal of Agronomy 50(3): 203 205.

Mugwe, J., Mugendi, D., Kungu, J. and Mucheru-Muna, M. 2007. Effect of plant biomass, manure and inorganic fertiliser on maize yield in the central highlands of Kenya. African Crop Science Journal 15(3): 111-126.

Nagalakshmi, K.V.V., Chandrasekhar, K. and Subbaiah, G. 2006. Weed management for efficient use of nitrogen in rabi maize. Andhra Agricultural Journal 53(1\&2): 14-16.

Ogundare, K., Agele, S. and Aiyelar, P. 2012. Organic amendment of an ultisol: effects on soil properties, growth, and yield of maize in Southern Guinea savanna zone of Nigeria. International Journal of Recycling of Organic Waste in Agriculture 1: 11.

Patel, V.J., Upadhyay, P.N., Zala, S.V. and Patel, B.D. 2006. Residual effect of herbicide applied as alone and mixture to kharif maize on succeeding rabi oat and mustard. Indian Journal of Weed Science 38(3\&4): 258-262.

Patidar, M. and Mali, A. L. 2002. Residual effect of farm yard manure, fertilizer and biofertilizer on succeeding wheat (Triticum aestivum). Indian Journal of Agronomy 47: 26-32.

Rao, A.S., Ratnam, M. and Reddy, T.Y. 2009. Weed management in zero-till sown maize. Indian Journal of Weed Science 41(1\&2): 46-49.

Salim, M., Kumar, M.K. and Kumar, S. 2015. Seasonal variation in some chemical characteristics of the soil under different land uses of Jhilmil Jheel wetland, Haridwar-Uttrakhand, India. International Journal of Scientific and Research Publications 5(10): 1-9.

Sarma, C.K. and Gautam, R.C. 2010. Weed growth, yield and nutrient uptake in maize (Zea mays) as influenced by tillage, seed rate and weed control methods. Indian Journal of Agronomy 55(4): 299-303.

Sekhon, N.K. and Agarwal, G.C. 1994. Change induced in maize leaf growth and development by organic amendments and $\mathrm{N}$ fertilization a calcareous ustochrept soil in north western India. Arid Soil Research and Rehabilitation 8:261-268.

Silva, P.S.L., Silva, J., Oliveira, F.H.T., Sousa, A.K.F. and Duda, G.P. 2006. 
Residual effect of cattle manure application on green ear yield and corn grain yield. Horticultural Brasileira 24: 166-169.

Tiwari, A., Dwivedi, A.K. and Dikshit, P.R. 2002. Longterm influence of organic and inorganic fertilization on soil fertility and productivity of soybean wheat system in a Vertisol. Journal of Indian Society of Soil Science 50: 472475.

Uchino, H., Iwama, K., Jitsuyama, Y., Yudate, T. and Nakamura, S. 2009. Yield losses of soybean and maize by competition with interseeded cover crops and weeds in organic-based cropping systems. Field Crops Research 113: 342-351.

Walkey, A. and Black, C.A. 1934. An examination of the method for determination of soil organic matter and proposed modification of the chromic acid titration method. Soil Science 37: 29-39.

Wen, G., Winter, J.P., Voroney, R.P. and Bates, T.E. 1997. Potassium availability with application of sewage sludge and sludge and manure composts in field experiments. Nutrient Cycling in Agroecosystems, 47: 233-241.

\section{How to cite this article:}

Moasunep, J.K. Choudhary and Khumdemo Ezung, N. 2019. Study on Maize-Sesamum Cropping System as Influenced by Weed and Organic Nutrient Management on Yield and Soil Health under Rainfed Condition of North East India. Int.J.Curr.Microbiol.App.Sci. 8(09): 398414. doi: https://doi.org/10.20546/ijcmas.2019.809.049 